\title{
The Effect of Regional Gross Domestic Product (GDP) and Development Expenditure on Employment in the District Luwu
}

\author{
I Ketut Patra, Sri Wahyuny \\ STIE Muhammadiyah Palopo, Indonesia \\ halim.stiemlecture@gmail.com
}

\begin{abstract}
This study aims to assess the economic growth and the factors that influence the economic growth in the local government system by increasing the production of goods and services measured by Gross Domestic Product (GDP) and the policy of government expenditure (development) that can directly drive growth to finance economic development in the field of social economy and the public, both the development of physical and non-physical. This study uses multiple regression analysis by the least squares method (Method of Ordinary Least Square) OLS. These results indicate that the budget Revenue Expenditure Luwu, particularly in development spending has been a major contribution to regional development Luwu. With increasing economic growth and rising Luwu regency Regional Budget Builders Luwu district each year, then it will affect the employment opportunities for local people Luwu.
\end{abstract}

Keywords: Regional Gross Domestic Product (GDP), expenditure development, employment opportunities

\section{Introduction}

Economic development of a region is essentially a series of activities carried out consciously and continuously to achieve a better state together and continuously. Within that framework, as well as to spur economic development and equitable development results in order to improve the welfare of the people in a fair and equitable. One important measure in determining the success of economic development is economic growth represents a real impact on development policies implemented. Economic growth is closely related to the process of increasing the production of goods and services in the local economy. Based on Law No. 32 of 2004 on Regional Government and Law No. 33 of 2004 on Financial Balance between Central and Local Government, has changed the concept and existing regional authority for this. This legislation has a substantial significance in providing the regional authority which was originally addressed on the basis of the portion of the policy that stands in the center of the central-local division of authorities subsequently directed into the region's autonomy in managing the region including financing policies.

\section{Literature Review}

The logical consequence of this impact on the progress of the regional economy and ultimately the creation of an increase in regional development with regard to the potential and diversity of the regions. The Irish Government has set ambitious economy importance of a sector in consul targets for growth in this sector in its Food tancy studies and by lobby groups seeking Harvest 2020 (FH2020) report (DAFF to stress the importance of their industry 2010b). These include: (i) an increase in to the economy and to justify receiving the value of primary output in the agricul- special incentives, has brought multiplier true, fisheries and forestry sector of 33\% analysis into a state of disrepute. During compared to the 2007-2009 average; (ii) the brief period of full employment in an increase in the output of the agri-food, the Irish economy in the mid2000s the fisheries and wood products processing (Ana, 2014) Therefore, it has become demand areas to be able to develop their potential to enhance the economic growth of the region. The accumulation of capital (capital accumulation) includes all kinds of new investment both by government or private implanted with landform, physical equipment, and capital resources. Capital accumulation would happen if the majority of the revenue is reinvested with the aim to increase output or income in the future. The accumulation of capital by the government describe how large the government role in the economy of a regional system. However, in certain cases shows that the market mechanism has the disadvantage of failing to achieve efficient allocation caused by the common goods, the element of market imperfections, public goods, externalities, incomplete 
markets, information failure, unemployment and uncertainty. MenghIndari For this, we need government intervention in the economy so that the allocation of economic resources can be achieved efficiently. During this time a lot of debate about how much the role that should be done by the government, the impact of the change in investments was greater than the impact of change in GDP on the Amman Stock Exchange index (Abedalfattah, 2012). This is because each person is different in the assessment of the cost of the benefits of the programs created by the government. But there is no doubt that people's lives have been very dependent on services provided by the government.

The existence of the Regional Budget (APBD) which is sourced from the help center and local revenue is a form of capital accumulation government used to encourage economic development in a region. Strategic role of public investment is targeted use to finance development in the field of infrastructure that can support the private business and the fulfillment of the public service. The limitations faced by the local government require a correct policy of the government. Efforts to increase local revenues can be done in conditions and specific items only, because in general these efforts can actually increase the burden on society. A policy perspective that can be done is through government spending policies. The policies outlined in the budget require attention, especially in terms of the distribution of the budget, so as to create new sources of revenue for the region. Government spending policies which can directly stimulate economic growth is the development expenditure since this variable is in the form of economic and social infrastructure such as roads, bridges and infrastructure development sectors of the economy. Not be separated from the budget, which many support a development in an area is how much ability they improve the local leader potential sectors contained in the area. The power sector will provide a good potential for a better impact on revenue (PAD). For some areas may be in the development stage will have the challenge to increase the potential sectors. Economic growth in the local government system is usually indicated by the increased production of goods and services measured by Gross Domestic Product (GDP).

Economic growth should be able to show an increasing trend and steady from year to year, due to high economic growth needed to accelerate changes in the structure of the regional economy towards a balanced and dynamic economy. Economic growth is also necessary to mobilize and spur development in other areas as well as the main force of development in order to increase people's income and overcoming socioeconomic inequality. One of the factors that influence the economic growth is human resources that exist in the region. Population increased from time to time may be driving or inhibiting the growth of the economy. Growing population will increase the amount of labor and allows the addition of an area to increase production. But on the other hand, the adverse consequences of population growth to economic growth faced by the people that its economic growth rate is still low. Natural resources themselves do not necessarily enhance economic growth in the short-run. But still domestic investment in resource industries may be quite productive, especially if it is associated with exports (Svetlana, 2008). Thus resources may positively influence economic growth through investment variable. However further research is needed to prove this proposition This means that the excess amount of the population is not balanced with other factors of production are available where additional labor will not cause any increase in the production rate. Policymakers are divided as to whether government expansion helps or hinders economic growth.

Advocates of bigger government argue that government programs provide valuable "public goods" such as education and infrastructure. They also claim that increases in government spending can bolster economic growth by putting money into people's pockets; Policymakers are divided as to whether government expansion helps or hinders economic growth. Advocates of bigger government argue that government programs provide valuable "public goods" such as education and infrastructure. They also claim that increases in government spending can bolster economic growth by putting money into people's pockets (2015).In order to achieve the optimal level of R\&D investment, government policy should aim to bring private incentives in line with the social rate of return. The first part of this note considers current estimates of the private and social rates of return to R\&D. These estimates suggest that the gap between private and social rates of return is quite large. A comparison of the levels of R\&D intensity in the business sector is then made across countries. The UK has the lowest R\&D intensity of the G5 countries and, perhaps more worryingly, the trend has been flat while in other countries R\&D intensity has been increasing over time. This is reflected in lower productivity levels in the UK (although there is much debate over the measurement of productivity and the size of this gap), (Rachel, 2000).Luwu is one of the districts in this period is still 
classified as a district under construction / development. Based on the Central Statistics Agency (BPS) in 2008 Luwu economic development amounted to $12.37 \%$ and in 2012 Luwu district economic development by $16.33 \%$. So the economic development of Luwu in parentheses period of 3 years (2008-2012) increased by $3.96 \%$.

Meanwhile seen from the development of the business of the year 2008-2012 (nine sectors), namely: agricultural sector in $2008 \mathrm{Rp} .819 .435,59$ in $2012 \mathrm{Rp} .1 .850 .037,78$, the mining sector in $2008 \mathrm{Rp} .15 .544,03$, whereas in 2012 USD. 28075.20, the industrial sector in 2008 USD.146,646.69, in 2012 USD.266,232.00, electricity, gas and water supply in 2008 USD. 2922.57 in 2012 USD. 7230.06, the building sector in 2008 89588.53, in 2012 Rp.263.191,85, trade, hotels, restaurants in 2008 Rp.112.725,59 in 2012 Rp.415.081,90, transport and communications sector in 2008 Rp.23.461,72 in 2012 USD. 65677.26, financial leasing and services company in 2008 USD. 30811.47 while in 2012 Rp.92.480,57, services in 2008 Rp.159.202,88 in 2012 USD. 729,626.30, then in terms of the labor force in accordance with the data, in 2012 employment in agriculture, forestry, hunting and fishing are men 76054,67543 Total 143597 women, employment in manufacturing, male 3,322, total 5932 women, 9254, in the field of large trades, retail, restaurant and hotel, 6357 men, women, total 2133627 693, social services, social and individual, male 8951, female, total 15604 24 555, and so on Other (mining and quarrying, electricity, gas and water, construction, transport, storage and communication, finance, insurance, leasing of buildings, land and services companies) male 9045 , female 1010 , a total of 10,055 .

Increased economic growth is a challenge for Local Government Luwu. Construction of various facilities and infrastructure as well as the alleviation of unemployment is also the home to the work of local government that is not easy to do. Based on the explanation above background, the authors raise a Title Proposal, namely Effect of Gross Domestic Product (GDP) and Development Expenditure Against Employment in Luwu. Existing evidence suggests that government subsidies stimulate business R\&D expenditure. However, most studies fail to address the possibility that part of the observed increase in expenditure may be due to higher R\&D wages. We consider the impact of different government subsidies on R\&D workers in 25 OECD countries and find that the short run tax-price elasticity of R\&D employment is marginally higher than existing estimates of the elasticity of expenditure with respect to the tax price of both labor and capital combined. We conclude that there is no evidence to indicate that wage inflation has seriously conflated past estimates of the effectiveness of government R\&D subsidies (Russell \& Paul, 2013) The problems of this study are (1) How much influence the Gross Domestic Product (GDP) on employment in Luwu and (2) How much influence the development expenditure on employment in Luwu. The purpose of this paper is (1) To determine how much influence GDP in Luwu on employment in Luwu. (2) To determine how much influence the development expenditure on employment in Luwu.

\section{Methodology}

This research is a quantitative research using secondary data. Data used in the study of time series data collected from 2009 through 2012, this study using quantitative analysis techniques, analysis techniques were used to estimate the parameters. The analytical method used is regression analysis used is multiple regression with the least square method (Method of Ordinary Least Square) OLS. This method is believed to have properties that can be seeded is technically very accurate, easy to interpret calculation as well as a linear estimation tools and best Unbiased (Nurmanaf, 1999). The regression model in question, namely:

$\mathrm{Y}=\alpha+\beta_{1} \mathrm{X}_{1}+\beta_{2} \mathrm{X}_{2}+\varepsilon_{\mathrm{i}}$

Or:

$\mathrm{Y}=\mathrm{a}+\mathrm{b}_{1} \mathrm{X}_{1}+\mathrm{b}_{2} \mathrm{X}_{2}$

Description:

$\mathrm{Y} \quad=$ the dependent variable (employment)

$\mathrm{X}_{1}=$ potential sectors

$\mathrm{X}_{2} \quad=$ shopping development

a $\quad=$ intercept estimators for $\alpha$ (point cut)

$\mathrm{b}_{1} \quad=$ estimator for $\beta_{1}$ 


\section{Results and Discussion}

Welfare of the population is the main target of development, as set out in the Medium Term Development Plan (Plan). This goal may not be achieved if the government cannot solve population problems, such as the large number of population and the uneven spread of population. Various attempts to suppress the high population growth rate have been carried out. Similarly, efforts that lead to equitable welfare of the population have always been done by moving the residents of a densely populated area to the area that is considered not solid.

Table 1: Population growth Luwu Year 2008 - 2011

\begin{tabular}{ll}
\hline Year & Total population(soul) \\
\hline 2008 & 317794 \\
2009 & 320205 \\
2010 & 324229 \\
2011 & 328180 \\
\hline
\end{tabular}

Source: BPS Luwu

Table 2:Table GDP Luwu Year 2007-2011

\begin{tabular}{|c|c|c|c|c|c|c|c|}
\hline Year & $\begin{array}{l}\text { GDP ADH } \\
\text { Prevail } \\
\text { (Million } \\
\text { Rupiah) } \\
\end{array}$ & $\begin{array}{l}\text { Growth } \\
\text { OAK (\%) }\end{array}$ & $\begin{array}{l}\text { GDP ADH } \\
\text { Consumer } 2000 \\
\text { (Million) }\end{array}$ & $\begin{array}{l}\text { Growth. } \\
\text { Economic } \\
(\%)\end{array}$ & $\begin{array}{l}\text { Development } \\
\text { Shopping } \\
\text { (USD) }\end{array}$ & $\begin{array}{l}\text { Lift } \\
\text { Work }\end{array}$ & an \\
\hline 2007 & $2,254,158.20$ & 14.51 & $1,400,339.46$ & 5.53 & $35,215,457.144 .00$ & 102324 & \\
\hline 2008 & $2,696,359.14$ & 19.62 & $1,480,669.07$ & 5.74 & $\begin{array}{l}36,025,365 \\
546.00\end{array}$ & 114338 & \\
\hline 2009 & $3,195,646.47$ & 18.52 & 1.581 .663 .42 & 6.82 & $\begin{array}{l}38,333,867 . \\
422.00\end{array}$ & 125932 & \\
\hline $2010 *$ & $3,717,632.93$ & 16.33 & $1,691,511.74$ & 6.95 & $\begin{array}{l}40,678,125 . \\
106.00\end{array}$ & 138146 & \\
\hline 2011 ** & $4,351,150.40$ & 17.04 & $1,817,943.58$ & 7.47 & $\begin{array}{l}40,899,857 . \\
376.00\end{array}$ & 141864 & \\
\hline
\end{tabular}

Source: BPS Luwu district

Note: * preliminary figures and figures ** Very Meanwhile

Based on Table 1 of the Population Growth In Luwu, show that each year, from 2008 to 2011, Luwu growing population of 10386 inhabitants or population growth each year with an average of 2,597 inhabitants. While projections of population distribution Luwu district by district, can be seen in the following table. The following table is presented Luwu GDP, 2007-2011. Based on Table 2, showing that economic development had been developed. Seen through the amount of GDP ADH applies in a given year compared with the previous year. While economic growth can be seen from the magnitude of the value of GDP at Constant 2000 ADH in a given year compared with the previous year. In 2011, GDP ADH Applicable Luwu reached a value of 4,351,150.40 million. Compared to the year 2010, this figure increases considerably significant GDP, i.e. $633,517.47$ million. Or an increase of approximately $17.04 \%$. The same thing happened in 2010, 2009 and 2008. During that time brackets, GDP Luwu Applicable ADH is continuously increasing. If in 2007 the GDP ADH Applicable Luwu reached 2,254,158.20 million, in 2008 an increase of approximately 19.62\% to 2,696,359, 14 million and in 2009 returned an increase of approximately $18.52 \%$ to 3,195. 646.47 million. While over 2000 constant prices, GDP Luwu each year also increased continuously. In 2011, GDP at Constant 2000 ADH Luwu reached 1,817,943.54 million or an increase of approximately 120,431.84 million, growing to approximately $7.47 \%$ of the previous year. whereas in 2010 reached 1,691,511.74 million rupiah or increased approximately 109,848.32 million, or approximately $6.95 \%$ compared to the year 2009 amounting to $1,581,663.42$ million. During that time brackets, ADH GDP at Constant 2000Luwu increase of approximately $100,994.34$ million, or approximately $6.82 \%$. 
In terms of labor force in Luwu from 2007 to 2011 has increased up to 39540 inhabitants, or an average annual increase of the labor force 7908 people. In 2007 the labor force amounted to 102324 people, then in 2008 increased 114338 inhabitants. 2009 to 2011 each experienced increasing the number of labor force, i.e. 125932 inhabitants, 138146 inhabitants and 141864 inhabitants. By looking at the link between economic development and economic growth in Luwu, also indicated that it was also followed by the increase of the labor force each year. From the picture above, it can be interpreted bring local government as a regulator in the economy in Luwu has successfully implemented programs to support the economy in the region. The growth of the Real Economic Luwu, The following table is presented real sector growth Luwu Year 20072011.

Table 3: Real Sector Economic growth Luwu Year 2007-2011

\begin{tabular}{lllllll}
\hline \multirow{2}{*}{ Economic Sector } & Growth (\%) & & & \\
& \multirow{2}{*}{ Agriculture } & $\mathbf{2 0 0 7}$ & $\mathbf{2 0 0 8}$ & $\mathbf{2 0 0 9}$ & $\mathbf{2 0 1 0} *$ & $\mathbf{2 0 1 1}$ \\
\hline & M** \\
2 & Mining and excavation & 2.61 & 2.99 & 6.97 & 5.92 & 6.75 \\
3 & industry processing & 14.54 & -0.96 & 3.28 & 0.88 & 17.14 \\
4 & Electricity, gas and water supply & 3.65 & 7.39 & -3.03 & 3.56 & 1.74 \\
5 & Building & 18.86 & 12.34 & 4.82 & 11.03 & 16.46 \\
6 & Trade, hotels and restaurants & 18.00 & 8.32 & 6.76 & 3.93 & 12.69 \\
7 & Transport and communication & 7.65 & 20.20 & 14.37 & 18.59 & 14.92 \\
8 & Finance, leasing and business services & 7.65 & 8.59 & 8.13 & 23.42 & 10.44 \\
9 & Services & 6.38 & 5.73 & 8.13 & 23.42 & 10.44 \\
Economic growth & 5.53 & 5.74 & 6.82 & 3.33 & 3.36 \\
\hline
\end{tabular}

Source: BPS Luwu

Careful planning will bring development evenly, especially in building the economy of the people better. The following table is presented realize implementation of development Luwu Regency Year 2009-2011.

Table 4: Realization of the Development Luwu Year 2009-2011

\begin{tabular}{llll}
\hline Description & $\mathbf{2 0 0 9}$ & $\mathbf{2 0 1 0}$ & $\mathbf{2 0 1 1}$ \\
\hline Income & $19,337,923,976.93$ & $17,954,313,156.81$ & $17,949,245,833.00$ \\
Locally-generated revenue & $431,631,277,190.00$ & $65,871,050,894.00$ & $481,758,544,690.75$ \\
Fund Balance & $20,253,831,558.50$ & $65,871,050,894.00$ & $172,814,653,992.28$ \\
Other Income & $471,223,032,725.13$ & $550,140,644,148.61$ & $876.522 .111,616,03$ \\
legitimate & & & \\
Total income & & & \\
Shopping & $236,838,333,554.00$ & $303,104,764,755.00$ & $316,677,788,120.00$ \\
Indirect spending & & & \\
Personnel expenditure & & & $5,332,132,000.00$ \\
Flower shopping & $1,844,632,000.00$ & $3,020,000,000.00$ & $13,969,928,688.00$ \\
Shopping subsidies & $12,174,372,997.00$ & $13,900,300.00$ & \\
Shopping grants & & & $26,929,928,688.00$ \\
Betanja social assistance & $26,159,494,425.00$ & $26,777,825,106.00$ & $24,174,100.00$ \\
Shopping for results & $549,660,000.00$ & $291,405,600.00$ & 62,00 \\
Financial aid spending & $277,566,492,976.00$ & $333,207,895,761.00$ & $349,564,022,908.00$ \\
Shopping unpredictable & & & \\
Total & & & \\
Direct spending & & & \\
\hline
\end{tabular}




\begin{tabular}{llll}
\hline Personnel expenditure & & $18,193,002,600.00$ & $19.675,427.399,00$ \\
Spending on goods and services & $77,170,854,333.00$ & $81,949,594,983.00$ & $124,977,190,047.00$ \\
Capital expenditures & $108,499,836,233.00$ & $110,017,718,945.00$ & $161,544.847 .302,00$ \\
Total & $185,670,690,568.00$ & $210,160,316,528.00$ & $306,197,464,748.00$ \\
\hline
\end{tabular}

Source: DPKD Luwu

Based on Table 4, show that revenue source Luwu district from 2009 to 2011, which is sourced from the fund balance, which in 2009 amounted to Rp.431.631.277.190,00, then in 2010 amounted Rp.466.315.280.097,80 and in 2011 amounted to Rp.481.758.544.690,75. Then in terms of Government spending Luwu with a very large number, namely personnel expenditure. Both from 2009, in 2010 and in 2011. The major personnel expenses, respectively, in 2009 amounted to Rp.236.838.333.554,00, then in 2010 rose to Rp.303.104.764.755,00 and in 2011 Rp.31 rose to 6,677,788. 1 20.00.If you look at the types of expenditure / Luwu regency government expenditure, which pertained to development spending, i.e. spending grants, social assistance expenditure and expenditure financial aid. The amount of each such expenditure in the year 2411, namely Rp.46.231 .989.376,00.

Community Work Force by Sector Potential Luwu: If the views of potential sectors in the region is very promising Luwu. With the fertile region known, then it is possible for each of the labor force is easy to get a job. The following table is presented the public work force Luwu based on the potential of existing sectors:

Table 5:People Labor Force Based Luwu district Potential Sectors

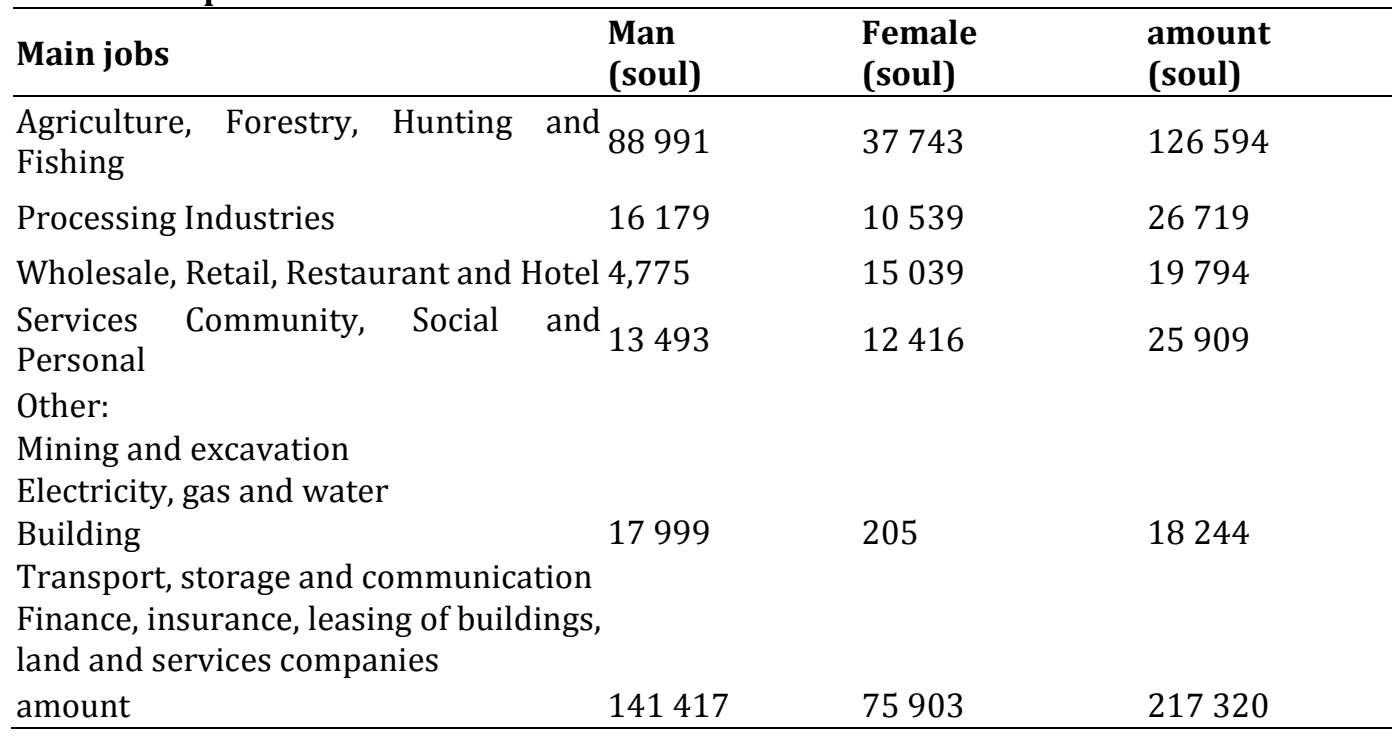

Source: BPS Luwu

Based on the table 5 above, shows that the absorption of labor in some sectors dominant the potential sectors of Agriculture, Forestry, Hunting and Fishing with the total labor force 126694 inhabitants. Followed by potential sectors, namely industry sector pengolan with a workforce of 26719 inhabitants, sector trade large, Eceren, social services, social and individual amounted to 25909 people, restaurant and hotel with a workforce of 19794 inhabitants and the last of the sector Other potential for 18.204. With a total workforce absorbed, i.e. 217320 inhabitants. By looking at the workforce successfully absorbed the total population in Luwu district, showed that the absorption of the labor force is quite good with a population of 328180 inhabitants. Meanwhile, the labor force can be separated between who had worked with who are seeking employment from 2009 to 2011 can be seen in the following table: 
Table 6:Community Work Force Luwu Year 2009-2011

\begin{tabular}{llll}
\hline Main jobs & $\mathbf{2 0 0 9}$ (soul) & $\mathbf{2 0 1 0 ( \text { soul) }}$ & 2011(soul) \\
\hline Work & 125932 & 138146 & 141861 \\
Find a job & 10807 & 9409 & 10516 \\
\hline
\end{tabular}

Source: BPS Luwu

From Table 6 it can be seen that the absorption of the labor force continues to grow each year. Where in 2009 the labor force is absorbed as much as 125932 people, in 2010 about 138146 inhabitants and in 2011 absorbed in the world of work as much as 141861 inhabitants. Later in terms of labor force is still looking for work continues to experience reductions. Where in the year 2009 as many as 10807 inhabitants, in 2010 dropped to 9409 inhabitants. But in 2011 increased the number of, as many as 10516 inhabitants.

Effect of Gross Domestic product (GDP) and expenditure on the construction of Employment Opportunities in Luwu: In looking at the effect of development expenditure to GDP and employment opportunities in Luwu, in addition to conducting interviews with interested parties, the authors have also been collecting data from parties and stakeholders. From the results of the questionnaire analysis using SPSS 18 to see the effect there. Here are the results of multiple regression calculation has been done.

Table 7: Multiple Linear Regression Analysis Coefficients ${ }^{a}$

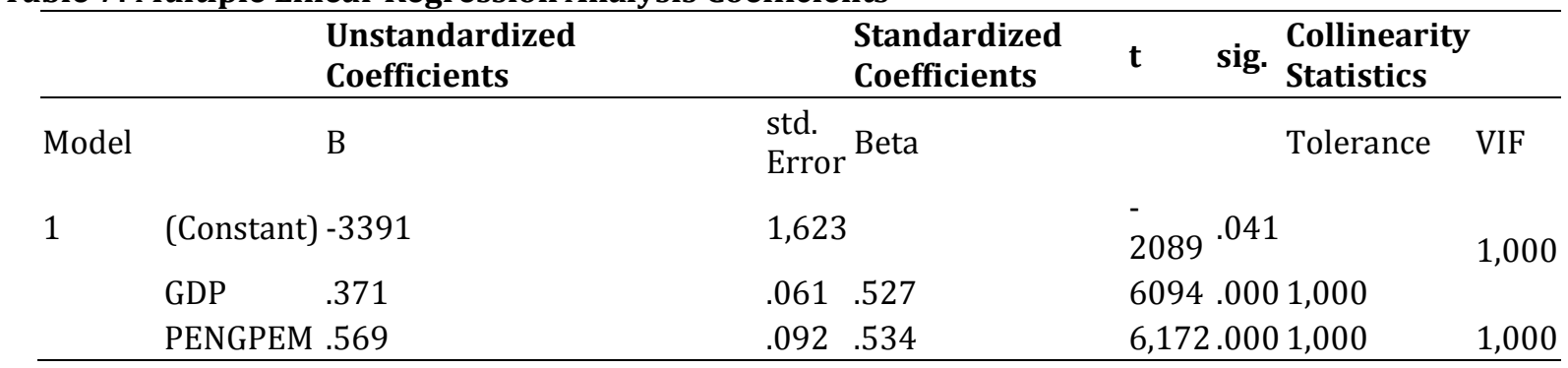

Source: Data Processed

Based on the table 7 above, the multiple linear regression equation:

$\mathrm{Y}=\mathrm{a}+\mathrm{b}_{1} \mathrm{X}_{1}+\mathrm{b}_{2} \mathrm{X}_{2}$

$\mathrm{Y}=-3391+0.371$ (GDP) +0.569 (development expenditure) From the equation above, it was explained that: $\mathrm{a}=$ constant -3391

This shows the magnitude of the effect of other factors on the labor force, meaning that if the independent variable is constant, then the opportunity / workforce decreased by 3,391 people.

$\mathrm{b} 1$ = regression coefficients for $\mathrm{X} 1=0.371$

This shows the magnitude of the effect of variable GDP on employment, meaning that if GDP increased by 1 rupiah variable, the value of job opportunities increased by 0.371 inhabitants assuming other variables constant.

b2 = regression coefficient for X2 $=0.569$

This shows the magnitude of the effect of variable development spending, meaning that if the variable construction spending rose 1 rupiah then employment would rise by 0.569 inhabitants.

T test and test F: Based on the table 7, then for the T test can be seen in the column sig (significance), where the probability of that column $<0.05$. It can be interpreted that there is influence between independent variable on the dependent variable. As for the F-test, ANOVA tables below are presented the results of the regression. 
Table 8: Multiple Linear Regression Analysis ANOVA b

\begin{tabular}{|c|c|c|c|c|c|c|}
\hline Model & & $\begin{array}{l}\text { Sum } \\
\text { Squares }\end{array}$ & ${ }^{\text {of }}$ Df & $\begin{array}{l}\text { Mean } \\
\text { Square }\end{array}$ & $\mathbf{F}$ & Sig. \\
\hline \multirow[t]{3}{*}{1} & Regression & 64580 & 2 & 32290 & 37378 & .000 \\
\hline & Residual & 50968 & 59 & .864 & & \\
\hline & Total & 115548 & 61 & & & \\
\hline
\end{tabular}

Source: Data Processed

From Table 8, show that the probability of sig (significance) $<0.05$, this means that the independent variable, dependent variable and regression models together can be used to predict the dependent variable. In other words that the relationship can apply to the population.

\section{Conclusion}

Based on the hypothesis that has been set and the results of research conducted by the author, the author can draw the following conclusion:

- Regional Domestic Product Bruto (GDP) Luwu since 2009 to 2011 increased significantly to reach $7.47 \%$ in the year 2011 run.

- The annual budget of Luwu, particularly in development spending has been a major contribution to regional development Luwu. It can be seen annually experience substantial increases, namely in 2011 budget for the construction reaches Rp, 1,429,254,929,488. Where the budget is comprised of the type of grant expenditure, social assistance spending and financial assistance spending.

- With increasing economic growth and rising Regions Luwu district's Budget Builders Luwu district each year, then it will affect the employment opportunities for local people Luwu. It can be seen each year, namely from the 2009 labor force can be absorbed as much as 115125 people, then in 2010 the labor force is absorbed as much as 128737 inhabitants and in 2011 a working can absorb a lot seb 131345 inhabitants.

Based on the research results and conclusions, then through this paper the authors hope: Economic Growth increased significantly each year would be comparable to the existing community economy. With the sense that society is not entirely uniform Luwu can enjoy existing development. To absorb the labor force over the next years, assuming Luwu regency government can create more job opportunities, provide guidance / counseling to the community to be able to open an independent business by utilizing the existing natural resources.

\section{References}

Ana, C. M. (2014). The employment effects of Food Harvest 2020 in Ireland. Irish Journal of Agricultural and Food Research, 53, 149-169.

Abedalfattah, Z. A. (2012). Impact of the investment and gross domestic production the Amman Stock Exchange index. Investment Management and Financial Innovations, 9(3).

Nurmanaf, A. R.(1999). The gap between Regional and Development Expenditures in the Indonesian province. Journal of Economics and Finance Indonesia, XLVll(4), 58-62

Rachel, G. (2000). How important is business R\&D for economic growth and should the government subsidize it? Institute for Fiscal Studies, October 2000, ISBN 1-903274-13-3

Russell, T. \& Paul, J. E.(2013). The effects of government subsidies on business R\&D employment: evidence from OECD countries. National Tax Journal, 66(2), 281-310.

Svetlana, L. (2008). Determinants of Economic Growth: Empirical Evidence from Russian Regions. The European Journal of Comparative Economics, 5(1), 87-105, ISSN 1722-4667 